\section{A1345 蛋白䊣の圧縮率を決定する構造因子の解析}

\author{
徳田 健治、○神山匡、月向邦彦（広島大·院理）
}

蛋白質の断熱圧縮率 $(\beta)$ は構造のコンパクトさと体積㠴ざを直 接反映する物理量であり、立体構造の個性を敏感に反映する。蛋白質 の摇らぎの発現機構を解明する上で、るを決定している構造因子を 明らかにすることは非常に重要である。近年の X 線結晶構造データ (PDB)の蓄皘により、蛋白質の内部空临である Cavity や溶媒露出表 面積 (ASA)をはじめ、種々の構造パラメータを算出、比較すること が可能となってきた。本研究では $\beta$ 既知の蛋白質 27 種類について、 立体構造データから得られた各種構造パラメー夕や一次構造と及の相 関を通して、压縮率に及ほす構造因子について考察した。

蛋白質の及に対して分子内の Cavity は正に寄与するが、27 種類の 蛋白質の Cavity を統計解析した結果、多くの Cavity は Moduleのよ うな構造単位の閵腺に位置すること、大きな Cavity ほど $\beta$ を高める 効果が大きいが約 $100 \AA^{3}$ 以上のサイズでは一定值に収束すること、 Cavityの平均の压繀率は約 $450 \times 10^{-6}(1 / \mathrm{bar})$ であることが明らかと なった。一方、単位質量当たりのASAが增すにつれてßは減少する 傾向にあり、水和がるに対して負の寄与を持っことと符合寸る。しか し、その相関が覀いことから $(\mathrm{r}=-0.243)$ 、種々の蛋白質の 3 の違いは 水和によるものではなく、主としてCavity(原子のパッキング状態)の 差異によりもたらされているものと考えられる。 $\alpha$-Helix と $\beta$-Sheet 含量の棇和と $\beta$ の間には高い正の相関 $(\mathrm{r}=0.792)$ があり、一次構造工 ニットは不完全なパッキングを通してダイナミックドメインとして作 用しているものと思われる。及は単位質量当たりのジスルフィド結合 の数が多いほど小さく $(\mathrm{r}=-0.823)$ 、ジスルフイド結合は摇らぎを抑制 する方向に作用していることがわかった。発表時にはこれらの解析結 果に加え、20種のアミノ酸との単相関解析、重回帰分析によるßの 予測などについても報告する予定である。

T. Tokuda, T. Kamiyama and K. Gekko : Stractural factors determining the compressibility of proteins

\section{A1415}

Detection of Two Conformers of a Mutant Carbonic Anhydrase by Force Microscopy

Alam Mohammad Taufiq, Ikai Atsushi (Faculty of Bioscience, Tokyo Institute of Technology)

Two conformers of a mutated bovine carbonic anhydrase II, having 259 amino acid residues, were detected by the force mode of atomic force microscope. Genetically engineered CAB (named CAB.Glu254Cys) was prepared by adding an extra cysteine residue at its N-terminus and replacing Glu254 with Cys to sandwich the protein molecule between a silanized surface of silicon wafer and a functionalized tip of an atomic force microscope (AFM). The genetically replaced Cys254 is located upstream of the knot structure, so that the protein could be stretched without forming a "knot" . Two distinct types of force-extension curves were observed when the protein was stretched by using the force mode of AFM, ne representing a nativelike and the other a softer conformation compared with the native conformation. The force curve representing the mechanical property of the latter conformation of $\mathrm{CAB}$ was not affected by the addition of the specific inhibitor, p-aminomethylbenzenesulfonamide, indicating its inability to bind with the inhibitor. The circular dichroism, fluorescence spectroscopy and affinity chromatographic data showed that the soft conformation has similar optical properties to those of the native $\mathrm{CAB}$ but lacks the active site. The present result suggests that the AFM can identify the two conformers of CAB by mechanical means. The result presented here is a novel and meaningful application of AFM in the detection and characterization of mechanically disbinguishable conformers in molecular scale.

M.T. Alam and A. Ikai : Detection of Two Conformers of a Mutant Carbonic Anhydrase by Force Microscopy

\section{$3 \mathrm{~A} 1400$ \\ タンパク質延伸のナノカ学}

○猪飼 篤（東工大·院·生命理工）

我タはポリペプチド鎖やタンパク質をその両端を含むいろいろな位 置から引っ張るという実験を通じて単一タンパク質分子の力学的特 性の一端を垣間見てきた。方法として原子間力顕微鏡の探針-基板間 に試料を共有結合架橋剮を用いてサンドイッチしてから探針-基板間 距離を增すことにより間の分子を延伸する。試料としてポリグル夕 ミン酸、炭酸デヒドラターゼ、カルモジュリン、G F P 他を使用し ている。特にN-末端とC-末端から延伸したポリグルタミン酸は全長 にいたるまで非線形ではあるが構造転移のないバネとして振舞うこ とがわかった。全長までの延伸に执いて分子に蓄積される「めがみ エネルギー」はヘリックス型、ランダムコイル形でそれぞれ、約 100 $\mathrm{kJ} / \mathrm{mol} / \mathrm{res}$ (idue) と $20 \mathrm{~kJ} / \mathrm{mol} / \mathrm{res}$ であった。炭酸デヒドラターゼを C-末端の knot 構造が出来ないように延伸すると全長の $70 \%$ までの 延伸で架橋構造が破壊されるまで張力は単調増加し、この時点までに

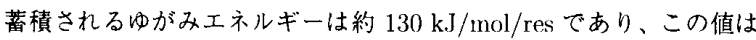
G F Pの場合も大きくは異ならない。立体構造をうまく生成できてい ない炭酸デヒドラターゼ分子種では、全長の半分程度までの延伸は容 易に進むが、全長までの延伸を行うには、平均 $40 \mathrm{~kJ} / \mathrm{mol} / \mathrm{res}$ の仕事 が必要となる。この值は水中における非特異的な残基間相互作用の大 きさに相当する。また knot 構造を保持したまま延伸すると、10 nm 以下の延伸でランダムコイルへの構造転移がおきる。これらの数值は 常温、水中でタンパク質立体構造を力学的に破填するには大きな仕事 を必要とすることを示唆しており、シャペロニンやタンパク質分解シ ステムにおいて提唱されているポリペプチド鎖の線形展開を定量的に 理解する上で参考となるであろう。また今後、ポリペプチド鎖やタン パク質の弾性的性質を利用した分子機械の設計も定量的に行えるよう になるであろう。

A lkai : Nano-Mechanics of Protein Stretching

\section{A1430}

\section{AFMを用いたぺプチドの 1 分子操作}

○武田 晴治 ${ }^{1} 、$ Ptak Arkadiusz ${ }^{1}$ 、中村 史 ${ }^{1}$ 、三宅 淳 ${ }^{1}$ 、影島 賢已 2 、Jarvis Suzanne ${ }^{2}$ 、德本洋志 ${ }^{2}$ (1 ${ }^{1}$ 工技院・融合研・バ イオ、2 工技院・融合研・アトム)

【序】生体内の現象を分子レベルで解明しようとするとき、1 分子レ ベルの操作、測定解析が求められるときがある。蛋白質、ペプチドの 構造はNMR、X 線結晶構造解析、CD スペクトル等樣々な方法で検討 されている。これらの方法から1分子レベルの構造の摇らぎ、変化等 の情報を得ることは容易ではない。そこで、原子間力顕微鏡 $(\mathrm{AFM})$ を用いて1分子レベルでのペプチドの構造及び特性について検討し た。まず、 $\alpha$ ヘリックス構造をとるペプチドを引き伸ばし、得られる フォースカーブの形状および引き伸ばしに必要な仕事からペプチド構 造について検討した。

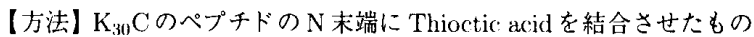
(TKC) を合成し、金基板上に TKC と Thioctic acid からなる自己組織 化単分子膜 (SAM 膜)を作製した。金でコーティングした AFM 探針 をSAM 膜に接触させ、金基板と探針の間に TKC 1 分子を金-チオー ル結合により結合させた。様々な条件で溶液中、探針と SAM 膜の距 離を離していく過程で針にかかる力を測定しフォースカーブを得た。 【結果及び考察】 poly-KはpH 11 以上で $\alpha$ ヘリックス構造をとること が知られている。 pH 11 の緩衝液中でフォースカーブを測定したとこ ろ、 $\alpha$ ヘリックスを形成している水素結合が切断されたと考えられる 点が複数観測された。この結果は、Lantzらにより報告されたフォー スカーブ 1)と類似している。8 $\mathrm{M}$ 尿素存在下で測定したところ、この ような点は観測されず、引き伸ばしに必要な仕事も大きく隇少した。 このことは、ペプチドの構造が変性していることを示唆している。ま た、 $\mathrm{pH}$ 、塩強度等が変化したときの結果についても調べ、AFMを用 いた1 分子レベルの操作、解析の可能性について検討寸る。

1) Mark A. Lantz et al. Chem. Phys. Lett. 315 (1999) 61-68.

S. Takeda, A. Ptak, C. Nakamura. J. Mivake, M. Kageshima, M. A. Lantz, S. P. Jarvis, H. Tokumoto : Stretching a single-peptide molecule under various conditions using AFM 